\title{
DISKRESI HAKIM DALAM PERKARA PERCERAIAN DAN HAK ASUH ANAK (STUDI DI PENGADILAN NEGERI PATI)
}

\author{
Amalia Eka Rizkiana, Yunanto \\ Program Studi Magister Kenotariatan \\ Fakultas Hukum, Universitas Diponegoro \\ Email : amaliaekriz@yahoo.co.id
}

\begin{abstract}
The Plaintiff is not permitted to change or add to the principal of the lawsuit clearly stipulated in the legislation, but in the Civil Case Number: 04 / Pdt.G / 2016 / PN.Pti in Pati District Court even though the Defendant in writing has refused to change and add the principal of the claim regarding child custody but in its ruling the Panel of Judges accepted the amendment as well as the addition of the principal lawsuit regarding child custody. The method in this study is an empirical juridical approach method with descriptive analytical research specifications. Based on the results of research and discussion it can be seen that the Panel of Judges in taking discretionary steps in their legal considerations argues that child custody is a case that follows from the principal case of divorce by observing parties who wish their marriage to break up due to divorce and mutual care for children from the marriages of the marriages. parties and for the sake of and see the principle in the justice system in the State of Indonesia is simple, fast and inexpensive so that the Panel of Judges in their legal considerations take steps to accept the changes and additions to the principal lawsuit on child custody so that in its decision can provide legal certainty, justice and benefit for litigants.
\end{abstract}

\section{Keywords: divorce case; changes to lawsuit; judge discretion}

\begin{abstract}
Abstrak
Tidak diperbolehkannya Penggugat mengubah atau menambah pokok gugatan sudah diatur jelas dalam perundang-undangan, namun dalam Perkara Perdata Nomor: 04/Pdt.G/2016/PN.Pti di Pengadilan Negeri Pati meskipun Pihak Tergugat secara tertulis telah menolak atas perubahan dan penambahan pokok gugatan mengenai hak asuh anak akan tetapi dalam amar putusannya Majelis Hakim menerima perubahan serta penambahan pokok gugatan mengenai hak asuh anak. Metode dalam penelitian ini adalah metode pendekatan yuridis empiris dengan spesifikasi penelitian berupa deskriptif analitis. Berdasarkan hasil penelitian dan pembahasan dapat diketahui bahwa Majelis Hakim dalam mengambil langkah diskresi dalam pertimbangan hukumnya berpendapat bahwa hak asuh anak adalah perkara yang mengikuti dari perkara pokoknya yaitu perceraian dengan memperhatikan para pihak yang berkeinginan perkawinannya putus karena perceraian serta saling ingin mengasuh anak dari hasil perkawinan para pihak dan demi dan memandang asas dalam sistem peradilan di Negara Indonesia adalah sederhana, cepat dan biaya murah sehingga Majelis Hakim dalam pertimbangan hukumnya mengambil langkah diskresi dan menerima perubahan serta penambahan pokok gugatan mengenai hak asuh anak sehingga dalam putusannya dapat memberikan kepastian hukum, keadilan dan kemanfaatan bagi para pihak yang berperkara.
\end{abstract}

Kata kunci : perkara perceraian; perubahan gugatan; diskresi hakim 


\section{A. Pendahuluan}

Perkawinan diatur dalam Undang-undang Nomor 1 Tahun 1974 tentang Perkawinan (UUP) ditegaskan bahwa Perkawinan ialah ikatan lahir batin antara seorang pria dan seorang wanita sebagai suami istri dengan tujuan membentuk keluarga (rumah tangga) yang bahagia dan kekal berdasarkan Ketuhanan Yang Maha Esa. Selain itu tujuan dari perkawinan adalah untuk melanjutkan keturunan. Kehadiran seorang anak merupakan kebahagiaan dan kesejahteraan bagi seorang ibu maupun keluarganya karena anak merupakan buah perkawinan dan sebagai landasan keturunan, maka dari itu orang tua harus memelihara dan merawat anaknya dengan cinta kasih, perhatian yang cukup termasuk pendidikan, kesehatan dan kecakapan.

Undang-undang Nomor 1 Tahun 1974 tentang Perkawinan dan hukum Islam memandang bahwa perkawinan itu tidak hanya dilihat dari aspek formal semata-mata, tetapi juga dilihat dari aspek agama dan sosial. Aspek agama menetapkan tentang keabsahan perkawinan, sedangkan aspek formal adalah menyangkut aspek administratif, sesuai dengan Pasal 2 Peraturan Pemerintah No. 9 Tahun 1975 tentang Pelaksanaan Undang-undang Nomor 1 Tahun 1974 tentang Perkawinan, yang dimaksud sebagai Lembaga Pencatat Perkawinan adalah Kantor Urusan Agama (KUA) bagi mereka yang melangsungkan Perkawinan secara Agama Islam dan Dinas Kependudukan dan Catatan Sipil (DINDUKCAPIL) bagi mereka yang melangsungkan Perkawinan menurut Agama selain Agama Islam

Perkawinan merupakan perbuatan yang penting dalam kehidupan manusia, karena merupakan bentuk pergaulan hidup manusia dalam lingkungan masyarakat sosial yang terkecil, tetapi juga lebih dari itu bahwa perkawinan merupakan perbuatan hukum dan perbuatan keagamaan. Negara mempunyai kepentingan pula untuk turut mencampuri urusan masalah perkawinan dengan membentuk dan melaksanakan perundang-undangan tentang perkawinan. Tujuannya untuk memberi perlindungan terhadap rakyat sebagai salah satu unsur negara, melalui hukum yang berlaku dan diberlakukan terhadap mereka.

Tidak ada seorang pun ketika melangsungkan perkawinan mengharapkan akan mengalami perceraian, apalagi jika dari perkawinan itu telah dikarunai anak. Namun demikian, biasanya ada sebab-sebab tertentu yang mengakibatkan perkawinan tidak dapat lagi diteruskan sehingga terpaksa harus terjadi perceraian antara suami istri (Muchtar, 2004). Sebagaimana yang diatur dalam Pasal 39 Undang-undang Nomor 1 Tahun 1974 tentang Perkawinan yang berbunyi sebagai berikut:

(1) Perceraian hanya dapat dilakukan di depan Sidang Pengadilan setelah Pengadilan yang bersangkutan berusaha dan tidak berhasil mendamaikan kedua belah pihak. 
(2) Untuk melakukan perceraian harus ada cukup alasan, bahwa antara suami isteri itu tidak akan dapat hidup rukun sebagai suami isteri.

(3) Tata cara perceraian di depan sidang Pengadilan diatur dalam peraturan perundang-undangan tersendiri.

Memilih bercerai, berarti harus berhadapan dengan pengadilan, sebab proses perceraian yang sah menurut hukum hanya dapat ditempuh melalui pengadilan saja. Guna melakukan perceraian salah satu pihak dari suami dan istri mengajukan permohonan atau gugatan cerai ke pengadilan. Adapun pengadilan yang berwenang memeriksa dan memutuskan perkara perceraian yaitu Pengadilan Agama bagi yang beragama Muslim dan Pengadilan Negeri bagi yang beragama Non Muslim.

Terjadinya perceraian maka akan berakibat bahwa kekuasaan orang tua berakhir dan berubah menjadi hak asuh. Oleh karena itu jika perkawinan diputus oleh Hakim maka perlu diputuskan tentang hak asuh terhadap anak-anak khususnya anak-anak yang masih dibawah umur. Di dalam Undang-undang Nomor 1 Tahun 1974 dalam Pasal 45 telah diatur mengenai hak dan kewajiban antara orang tua dan anak, kewajiban ini berlaku terus meskipun perkawinan antara kedua orang tuanya telah putus.

Independensi Kekuasaan Kehakiman merupakan bagian dari prinsip negara hukum yang demokratis. Prinsip demikian diperlukan untuk melindungi Kekuasaan Kehakiman dari intervensi, bujukan, rayuan, paksaan maupun pengaruh lembaga, teman sejawat, atasan atau pihak-pihak lain, sehingga Hakim dalam memutus perkara benar-benar berdasar pada keadilan hukum, rasa keadilan dan hati nurani. Kekuasaan Kehakiman harus dijalankan dengan tanpa tekanan atau intimidasi dari elemen-elemen pemerintahan lainnya. Dengan demikian reformasi di bidang Kekuasaan Kehakiman menjadi semacam keniscayaan karena dinamika hukum yang senantiasa berkembang dan kian kompleks menuntut kekuasaan yang ada di dalamnya untuk senantiasa diperbarui dan ditingkatkan akspetabilitasnya.

Hak asuh anak bisa saja jatuh ke tangan ayah atau ibu. Tetapi yang pasti tidak mudah bagi salah satu pihak yang tidak memenangkan putusan perkara dalam hak pengasuhan anak jika keinginannya itu tidak sesuai dengan kenyataan yang ada. Majelis Hakim bebas untuk menetapkan ayah atau ibu yang berhak memelihara anak tersebut, tergantung dari siapa yang dirasa cakap atau yang terbaik untuk kepentingan anak-anak tersebut. Di Pengadilan Negeri Pati misalnya Hakim dalam memutuskan perkara perceraian mengambil Diskresi dengan mengabulkan perubahan pokok gugatan yaitu menambah posita baru dan petitum tambahan mengenai hak asuh anak dari pihak penggugat yang bertentangan dengan Pasal $127 \mathrm{Rv}$ (Reglement Op De Rechtsvordering) yang berbunyi: 
"Penggugat berhak untuk mengubah atau mengurangi tuntutannya sampai saat perkara diputus, tanpa boleh mengubah atau menambah pokok gugatannya"

Mengingat Diskresi Hakim dalam mengabulkan perubahan pokok gugatan dalam suatu Perkara menunjukan independensi Kekuasaan Kehakiman yang harus menjadi perhatian lebih karena akan menentukan laju alir proses peradilan dalam mencapai kepastian hukum sehingga hal ini sangat menarik untuk dijadikan penelitian hukum.

Dalam menjawab problematika penelitian ini, Penulis menggunakan teori yang menjadi titik tolak atau landasan berpikir dalam memecahkan permasalahan. Teori berfungsi untuk menerangkan, memprediksi dan menemukan keterpautan fakta-fakta yang ada secara sistematik. Berangkat dari kebutuhan tersebut, teori yang dianggap paling tepat untuk memahami dan menjelaskan realitas sosial (hukum yang sedang dikaji) dalam penelitian mengenai diskresi Hakim dalam perkara perceraian dan hak asuh anak (studi di Pengadilan Negeri Pati) adalah Teori Dasar Hukum Triadism Law Theory dari Gustav Radbruch. Gustav Radbruch mengajarkan bahwa hukum harus memuat 3 (tiga) nilai dasar yaitu: nilai keadilan (aspek filosofis), nilai kepastian (aspek yuridis), dan nilai kemanfaatan (aspek sosiologis). Setiap peraturan hukum harus dapat dikembalikan keabsahannya pada 3 (tiga ) nilai dasar tersebut (Radbruch, 2013).

Mengingat Diskresi Hakim dalam mengabulkan perubahan pokok gugatan dalam suatu Perkara menunjukan independensi Kekuasaan Kehakiman yang harus menjadi perhatian lebih karena akan menentukan laju alir proses peradilan dalam mencapai kepastian hukum sehingga hal ini sangat menarik untuk dijadikan penelitian hukum dan menimbulkan pertanyaan terkait: 1) Bagaimanakah pelaksanaan Diskresi Hakim menurut Undang-undang Republik Indonesia Nomor 48 Tahun 2009 tentang Kekuasaan Kehakiman?; 2) Bagaimanakah pertimbangan Majelis Hakim untuk mengambil Diskresi dalam memutus suatu Perkara?

\section{B. Metode Penelitian}

Dalam jurnal ini, Penulis menggunakan metodologi penelitian sebagai berikut:

1. Metode Pendekatan

Berdasarkan perumusan masalah dan tujuan penelitian, maka metode pendekatan yuridis empiris yaitu suatu penelitian yang tidak hanya menekankan kepada hukum saja tetapi juga kenyataan pelaksanaan hukum dalam masyarakat (Soemitro, 1990a). Pendekatan yuridis empiris digunakan untuk menganalisis berbagai peraturan perundang-undangan di bidang perkawinan dan kehakiman dan digunakan untuk memberikan gambaran kualitatif tentang pelaksanaan diskresi kehakiman.

2. Spesifikasi Penelitian 
Spesifikasi penelitian yang digunakan adalah penelitian deskriptif analitis. Sesuai dengan namanya maka penelitian deskriptif analitis adalah suatu bentuk penelitian yang bertujuan untuk menggambarkan karakteristik dari objek yang diteliti kemudian dikaitkan dengan praktek pelaksanaan hukum positif yang menyangkut permasalahan yang diteliti (Soekanto, 1990).

3. Sumber dan Jenis Data

Jenis data yang dikumpulkan dalam penelitian ini dapat digolongkan menjadi dua yaitu

a. Data Primer, data yang diperoleh dari penelitian lapangan yaitu data secara langsung diperoleh dari informan dan nara sumber sebagai subjek penelitian, yaitu Hakim di Pengadilan Negeri Pati.

b. Data Sekunder, yaitu penelitian kepustakaan yang memiliki tujuan mencari, mempelajari dan mengumpulkan data sekunder yang berhubungan dengan obyek penelitian dengan melakukan studi dokumen terhadap buku-buku literatur, perundang-undangan, dan dokumen yang meliputi : bahan-bahan hukum, baik bahan hukum primer, bahan hukum sekunder, dan bahan hukum tersier (Soemitro, 1990b).

4. Teknik Pengumpulan Data

Dalam melakukan pengumpulan data penelitian, Penulis menggunakan dua teknik pengumpulan data yaitu, wawancara yang digunakan untuk mengumpulkan data primer dan kajian dokumen yang digunakan untuk mengumpulkan data sekunder.

5. Metode Analisis Data

Metode analisis data pada penelitian ini dilakukan secara kualitatif yang dinyatakan oleh responden/informan secara tertulis atau lisan serta tingkah laku yang nyata, yang diteliti dan dipelajari sebagai suatu yang utuh, setelah data terkumpul kemudian dituangkan dalam bentuk uraian logis dan sistematis.

\section{Hasil Dan Pembahasan}

\section{Pelaksanaan Diskresi Hakim Menurut Undang-Undang Republik Indonesia Nomor 48 Tahun 2009 tentang Kekuasaan Kehakiman}

Di Indonesia, kekuasaan kehakiman, sejak awal kemerdekaan juga diniatkan sebagai cabang kekuasaan yang terpisah dari lembaga-lembaga politik seperti MPR/DPR dan Presiden. Kekuasaan Kehakiman dalam konteks negara Indonesia adalah kekuasaan negara yang merdeka untuk menyelenggarakan peradilan guna menegakkan hukum dan keadilan berdasarkan Pancasila demi terselenggarannya negara Repubik Indonesia, kekuasaan 
kehakiman tidak mungkin dapat terlepas dari konstitusi yang berlaku di Indonesia, yaitu UUD 1945.

Dalam UUD 1945, pengaturan kekuasaan kehakiman ditempatkan pada Bab IX berjudul Kekuasaan Kehakiman, yaitu Pasal 24 ayat (1) mengatur bahwa "Kekuasaan kehakiman dilakukan oleh sebuah Mahkamah Agung dan lain-lain badang kehakiman menurut Undangundang", selanjutnya, Pasal 24 ayat (2) mengatur bahwa "Susunan dan kekuasaan badanbadankehakiman itu diatur dengan Undang-undang." Sementara itu, pengaturan mengenai rekrutmen dan pemberhentian Hakim diatur dalam Pasal 25 yang menyebutkan bahwa "Syarat-syarat untuk menjadi dan untuk diperhentikan sebagai hakim ditetapkan dengan Undang-undang."

Lebih lanjut tentang kekuasaan kehakiman yang merdeka kembali ditegaskan dalam Undang Undang Nomor 48 Tahun 2009 tentang Kekuasaan Kehakiman maupun dalam Undang-undang Nomor 14 Tahun 1985 tentang Mahkamah Agung sebagaimana telah dirobah dengan UU. No. 5 Tahun 2004 tentang Perubahan atas Undang-undang. No. 14 Tahun 1985 tentang Mahkamah Agung junto Undang-undang. No. 3 Tahun 2009 tentang Perubahan Kedua atas Undang-undang. No. 14 Tahun 1985 tentang Mahkamah Agung. Pasal 1 ayat (1) Undang-undang No. 48 Tahun 2009 tentang kekuasaan Kehakiman menegaskan bahwa Kekuasaan Kehakiman adalah kekuasaan Negara yang merdeka untuk menyelenggaraan peradilan guna menegakkan hukum dan keadilan berdasarkan Pancasila dan Undang-undang Dasar Negara Republik Indonesia Tahun 1945, demi terselenggaranya Negara hukum Republik Indonesia. Penegasan kedudukan kekuasaan kehakiman tersebut diatur dalam Pasal 2 Undang Undang No. 3 Tahun 2009 bahwa Mahkamah Agung adalah Pengadilan Negara Tertinggi dari semua lingkungan peradilan, yang dalam melaksanakan tugasnya terlepas dari pengaruh pemerintah dan pengaruh-pengaruh lainnya.

Hakim adalah profesi yang memiliki peran penting dalam mewujudkan tujuan hukum. Hakim mempunyai kewenangan memutus perkara yang disidangkan di peradilan berdasarkan kebijaksanaanya. Makna lebih jauh, Hakim tidak sebatas pada itu saja, Hakim memiliki makna filosofi jauh lebih mulia dari sekedar pemutus perkara dalam peradilan. Putusan hakim atau lazim disebut dengan istilah putusan pengadilan merupakan suatu putusan yang sangat dinantikan oleh pihak-pihak yang berperkara guna menyelesaikan sengketa diantara mereka dengan sebaik-baiknya dalam bentuk putusan hukum, tentu yang diharapkan oleh para pencari keadilan bahwa Pengadilan dapat memberikan putusan yang sesuai dengan tiga nilai dasar penopang hukum oleh Gustav Radbruch, disebut sebagai Idee des rechts (penopang cita hukum) yang mencakup keadilan, kemanfaatan dan kepastian hukum., namun seringkali 
ketiga nilai dasar tersebut tidak selalu berada dalam hubungan yang harmonis satu sama lain, melainkan berhadapan, bertentangan, ketegangan satu sama lain. Dalam hal terjadi pertentangan demikian, yang mestinya diutamakan adalah keadilan, hal ini karena pada hakikatnya hukum adalah untuk kepentingan manusia, bukan manusia untuk hukum.

Sebagai penegak hukum, hakim mempunyai tugas pokok di bidang yudisial, yaitu menerima, memeriksa, memutuskan, dan menyelesaikan setiap perkara yang diajukan kepadanya (Mertokusumo, 2003). Dalam melaksanakan tugasnya, Hakim merupakan pelaksana inti yang secara fungsional yang melaksanakan kekuasaan kehakiman. Kekuasaan kehakiman terletak dalam bidang yudikatif dengan kebebasan yang diatur dalam Undangundang.

Menegakkan hukum harus menguraikan makna dan tujuan hukum itu sendiri, bukan hanya menerapkan aturan perundang-undangan yang tertulis sehingga Hakim bukan hanya sebagai corong Undang-undang, namun Hakim wajib menghadirkan tujuan hukum yaitu keadilan, kemanfaatan dan kepastian hukum. Hakim wajib memutus perkara dengan keyakinannya serta dilandasi pada kebijaksanaannya (Haryadi \& Suteki, 2017).

Sejalan dengan tugas pokok tersebut, maka pengadilan tidak boleh menolak untuk memeriksa dan mengadili suatu perkara yang diajukan oleh yustisiabel dengan dalih bahwa hukumnya tidak ada atau kurang jelas. Hal ini berarti pengadilan wajib untuk memeriksa, mengadili dan memutus suatu perkara yang diajukan oleh pencari keadilan (Busthami, 2017).

Kekuasaan Kehakiman merupakan kekuasaan yang merdeka untuk menyelenggarakan peradilan guna menegakkan hukum dan keadilan. Dalam menjalankan tugasnya, tidak menutup kemungkinan Hakim akan dihadapkan pada perkara yang apabila didasarkan pada normatif Hukum mengalami kebuntuan legalitas formal, sehingga untuk menembus kebuntuan legalitas formal itu dibutuhkan diskresi Hakim dalam hal-hal tertentu yang memang tidak bisa dihindari dan sangat sulit sifatnya dalam menentukan dan menetapkan putusan sebuah perkara di Pengadilan.

Pengaturan Diskresi Hakim sebagai pengemban fungsi Yudikatif dapat ditemukan dalam Undang-undang Nomor 30 Tahun 2014 tentang Administrasi Pemerintahan yang diatur dalam ketentuan Pasal 1 angka 9, yang mengartikan bahwa diskresi adalah keputusan dan/atau tindakan yang ditetapkan dan/atau dilakukan oleh pejabat pemerintahan untuk mengatasi persoalan konkret yang dihadapi dalam penyelenggaraan pemerintahan, dalam hal peraturan perUndang-undangan tidak memberikan pilihan, tidak mengatur, tidak lengkap atau tidak jelas, dan/atau adanya stagnasi pemerintahan. Mengenai pejabat pemerintahan sebagaimana yang dimaksudkan dalam Pasal 1 ayat (9) diatur dalam Pasal 1 angka 3 yang 
menjelaskan bahwa Badan dan/atau Pejabat Pemerintahan adalah unsur yang melaksanakan fungsi pemerintahan, baik dilingkungan pemerintah maupun penyelenggara Negara lainnya.

Diskersi Hakim merupakan perwujudan dari Kekuasaan Kehakim yang merdeka, Hakim adalah Pejabat Negara sebagai Penyelenggara Negara dibidang Yudikatif yang memiliki peran penting dalam mewujudkan tujuan hukum, Hakim mempunyai kewenangan memutus perkara yang disidangkan di peradilan berdasarkan kebijaksanaanya, maka dapat disimpulkan bahwa pada hakekatnya diskresi merupakan kebebasan bertindak atau kebebasan mengambil keputusan dari Badan atau pejabat pemerintahan menurut pendapatnya sendiri sebagai pelengkap dari asas legalitas manakala hukum yang berlaku tidak mampu menyelesaikan permasalahan tertentu yang muncul secara tiba-tiba, bisa karena peraturannya memang tidak ada atau karena peraturan yang ada yang mengatur tentang sesuatu hal tidak jelas. Roscoe Pound, salah seorang penganut Sociological Jurisprudence memberikan pandangan bahwa keadilan dapat dilaksanakan dengan hukum atau tanpa hukum. Keadilan tanpa hukum dilaksanakan sesuai dengan keinginan atau intuisi seseorang yang di dalam mengambil keputusan mempunyai ruang lingkup diskresi yang luas serta tidak ada keterikatan pada perangkat aturan tertentu (Mertokusumo, 1988).

Hakim diberikan kekuasaan yang merdeka dalam memutuskan suatu perkara tanpa adanya intervensi dari kekuasaan Negara yang lainnya, kekuasaan kehakiman yang merdeka yang dijamin oleh konstitusi sebagai Upaya untuk memberikan jaminan rasa keadilan kepada masyarakat pencari keadilan sangat diharapkan hakim wajib memiliki kemampuan analisis hukum yang baik, integritas, moral dan etika. Diskresi Hakim merupakan perwujudan nyata dari Kekuasaan Kehakiman yang Merdeka berdasarkan Undang-undang, sehingga langkah diskresi hakim yang diambil dalam memutus suatu perkara dapat memberikan nilai keadilan (aspek filosofis), nilai kepastian (aspek yuridis), dan nilai kemanfaatan (aspek sosiologis).

\section{Mencermati Pertimbangan Majelis Hakim Dalam Perkara Perceraian Dan Hak Asuh}

\section{Anak Dalam Mengambil Diskresi}

Terjadinya perceraian maka akan berakibat bahwa kekuasaan orang tua berakhir dan berubah menjadi hak asuh. Oleh karena itu jika perkawinan diputus oleh Hakim maka perlu diputuskan tentang hak asuh terhadap anak-anak khususnya anak-anak yang masih dibawah umur. Di dalam Undang Undang Nomor 1 Tahun 1974 dalam Pasal 45 telah diatur mengenai hak dan kewajiban antara orang tua dan anak, kewajiban ini berlaku terus meskipun perkawinan antara kedua orang tuanya telah putus.

Hak asuh anak bisa saja jatuh ke tangan ayah atau ibu. Tetapi yang pasti tidak mudah bagi salah satu pihak yang tidak memenangkan putusan perkara dalam hak pengasuhan anak 
jika keinginannya itu tidak sesuai dengan kenyataan yang ada. Majelis Hakim bebas untuk menetapkan ayah atau ibu yang berhak memelihara anak tersebut, tergantung dari siapa yang dirasa cakap atau yang terbaik untuk kepentingan anak-anak tersebut.

Dalam konteks yang lebih spesifik, yaitu ketika Hakim dihadapkan pada perkara yang apabila didasarkan pada normatif Hukum mengalami kebuntuan legalitas formal, sehingga untuk menembus kebuntuan legalitas formal itu dibutuhkan diskresi Hakim dalam hal-hal tertentu yang memang tidak bisa dihindari dan sangat sulit sifatnya dalam menentukan dan menetapkan putusan sebuah perkara di Pengadilan.

Dalam suatu perkara perceraian yang diajukan di Pengadilan Negeri Pati, Hakim dalam memutuskan suatu perkara perceraian dalam pertimbangan hukumnya mengambil Diskresi dengan mengabulkan perubahan pokok gugatan Penggugat, yaitu ditambahkannya posita baru dan petitum tambahan mengenai hak asuh anak yang mana peubahan dan penambahan pokok gugatan bertentangan dengan Pasal $127 \mathrm{Rv}$ (Reglement Op De Rechtsvordering) yang berbunyi "Penggugat berhak untuk mengubah atau mengurangi tuntutannya sampai saat perkara diputus, tanpa boleh mengubah atau menambah pokok gugatannya"

Terkait Perubahan Posita dan Petitum yang dilakukan oleh Penggugat Konvensi/Tergugat Rekonvensi, Majelis Hakim telah menanyakan langsung kepada Tergugat Konvensi/Penggugat Rekonvensi yang ditanggapi oleh Tergugat Konvensi/Penggugat Rekonvensi dengan menyerahkan hukumnya kepada Majelis Hakim atas perubahan Posita dan Petitum tersebut meskipun dalam Jawaban Tergugat Konvensi/ Penggugat Rekonvensi dalam eksepsinya secara tegas menolak Perubahan Gugatan tersebut yang menurut Tergugat Konvensi/Penggugat Rekonvensi bukan merupakan sebuah revisi mengenai pembetulan penulisan melainkan merupakan gugatan baru karena telah menambah Posita dan Petitum Gugatan mengenai hak asuh anak dan tetap mengakui gugatan semula yang tidak menyertakan mengenai hak asuh anak.

Pengaturan mengenai perubahan gugatan tidak diatur dalam HIR (Herziene Indonesich Reglement) RBg maupun (Rechtsreglement Buitengewesten) melainkan diatur dalam Pasal $127 \mathrm{Rv}$ (Reglement Op De Rechtsvordering) yang berbunyi: "Penggugat berhak untuk mengubah atau mengurangi tuntutannya sampai saat perkara diputus, tanpa boleh mengubah atau menambah pokok gugatannya”. Berdasarkan ketentuan dari bunyi pasal tersebut, dapat ditarik kesimpulan bahwa penggugat memiliki hak untuk mengajukan perubahan gugatan, namun hanya yang bersifat mengurangi atau tidak menambah dasar daripada tuntutan dan peristiwa-peristiwa yang menjadi dasar tuntutan. Penambahan Posita dan Petitum Gugatan oleh Penggugat Konvensi/Tergugat Rekonvensi jelas bertentangan dengan bunyi Pasal 127 
Rv (Reglement Op De Rechtsvordering) dan seharusnya Majelis Hakim menerima Eksepsi dari Tergugat Konvensi/Penggugat Rekonvensi.

Kekuasaan Kehakiman yang merdeka dalam menyelenggarakan peradilan guna menegakkan hukum dan keadilan tidak menutup kemungkinan Hakim akan dihadapkan pada perkara yang apabila didasarkan pada normatif Hukum mengalami kebuntuan legalitas formal, sehingga untuk menembus kebuntuan legalitas formal itu dibutuhkan Diskresi Hakim dalam hal-hal tertentu yang memang tidak bisa dihindari dan sangat sulit sifatnya dalam menentukan dan menetapkan putusan sebuah perkara di Pengadilan.

Diskresi Hakim dalam memutus suatu perkara di Pengadilan merupakan salah satu wujud penerapan hukum progresif untuk mewujudkan keadilan bagi masyarakat dan tidak hanya mempertimbangkan hukum sebagai suatu keharusan, benar atau salah menurut pasalpasal dalam Undang-undang, ataupun dogma dan asas hukum, sehingga Hakim dalam memutus suatu perkara tidak hanya mengindentikan hukum dengan Undang-undang yang bertujuan untuk menjamin kepastian hukum tanpa memperdulikan keadilan dan manfaatnya bagi masyarakat.

Pemikiran hukum progresif dalam hubungan dengan perwujudan keadilan, pernah pula dikemukakan oleh salah seorang hakim Agung, Bismar Seregar, dengan menyatakan "Bila untuk menegakan keadilan saya korbankan kepastian hukum, akan saya korbankan hukum itu. Hukum hanya sarana sedangkan tujuannya adalah keadilan, mengapa tujuan dikorbankan karena sarana (Darmodihardjo \& Sidharta, 1995). Dengan demikian hakim dalam menerapkan hukum progresif untuk mewujudkan keadilan sosial sebagai keadilan substantif harus berani untuk mengesampingkan substansi hukum yang dinilai buruk dan menghambat pencapaian keadilan sosial masyarakat.

Penerapan Hukum Progresif sebagaimana diuraikan diatas juga diterapkan oleh Majelis Hakim dalam Perkara Nomor : 4/Pdt.G/2016/PN.Pti dalam pertimbangan hukumnya dalam mengambil Diskresi Hakim dalam menolak eksepsi atas penambahan Posita dan Petitum Gugatan sebagaimana Pertimbangan Hukum Majelis Hakim yang berbunyi :

Menimbang, bahwa Majelis Hakim juga memandang asas dalam sistem peradilan dinegara Indonesia adalah sederhana, cepat dan biaya murah sehingga Majelis Hakim tidak bisa hanya berlandaskan formalitas terhadap semua hal, dalam perkara A quo Majelis Hakim memandang permasalahan hak asuh anak merupakan permasalahan yang mengikuti dari permasalahan pokoknya yaitu perceraian sehingga Majelis Hakim memandang bahwa perubahan tersebut dapat diterima daripada pada akhirnya nanti akan diajukan gugatan baru dan dalam gugatan Rekovensi permasalahan hak asuh anak ini juga dimintakan, 
sehingga diskresi Majelis Hakim dalam hal menerima perubahan Gugatan Penggugat konvensi/Tergugat Rekonvensi sesuai dengan sistem peradilan yaitu sederhana, cepat dan biaya murah;

Pengaturan Diskresi Hakim sebagai pengemban fungsi Yudikatif dapat ditemukan dalam Undang-undang Nomor 30 Tahun 2014 tentang Administrasi Pemerintahan yang diatur dalam ketentuan Pasal 1 angka 9, yang mengartikan bahwa diskresi adalah keputusan dan/atau tindakan yang ditetapkan dan/atau dilakukan oleh pejabat pemerintahan untuk mengatasi persoalan konkret yang dihadapi dalam penyelenggaraan pemerintahan, dalam hal peraturan perUndang-undangan tidak memberikan pilihan, tidak mengatur, tidak lengkap atau tidak jelas, dan/atau adanya stagnasi pemerintahan. Mengenai pejabat pemerintahan sebagaimana yang dimaksudkan dalam Pasal 1 ayat (9) diatur dalam Pasal 1 angka 3 yang menjelaskan bahwa Badan dan/atau Pejabat Pemerintahan adalah unsur yang melaksanakan fungsi pemerintahan, baik dilingkungan pemerintah maupun penyelenggara Negara lainnya.

Pertimbangan Majelis Hakim dalam mengambil Diskresi dengan mengenyampingkan Pasal $127 \mathrm{Rv}$ adalah bentuk dari integritas Hakim dalam menggali dan melihat hukum sebagai sarana untuk mewujudkan keadilan sosial dalam memberikan kepastian hukum untuk menerima atau menolak eksespsi atas perubahan gugatan tersebut dengan terlebih dahulu memperhatikan secara utuh dan menyeluruh keinginan para pihak yang berperkara dalam persidangan.

Mencermati Diskresi Majelis Hakim dalam hal menerima perubahan Gugatan Penggugat Konvensional/Tergugat Rekonvensi didasarkan pada Sistem Peradilan Yaitu Sederhana, Cepat dan Biaya Murah, hal tersebut sebagaimana yang dimuat dalam Bunyi Pasal 2 ayat (4) Undang Undang No 48 Tahun 2009 tentang Kekuasaan Kehakiman yang berbunyi "Peradilan dilakukan dengan Sederhana, Cepat, dan Biaya Ringan".

Keadilan Menurut Gustav Radbruch dibedakan dalam beberapa arti:

1) Keadilan sebagai keutamaan atau kebajikan (Gerechtigkeit als Tugend), yaitu keadilan sebagai sifat atau kualitas pribadi (misalnya bagi seorang hakim). Di sini ada keadilan subjektif, dan keadilan sebagai sifat atau kualitas hubungan antar manusia (misalnya harga yang adil). Keadilan subjektif adalah pendirian atau sikap, pandangan dan keyakinan yang diarahkan kepada terwujudnya keadilan objektif sebagai keadilan yang primer. Sementara keadilan subjektif adalah sekunder. Apa itu keadilan objektif, kurang begitu jelas.Barangkali dalam pandangan Radbruch, keadilan objektif itu adalah keadilan dalam hubungan antar manusia. 
2. Keadilan menurut ukuran hukum positif dan keadilan menurut cita hukum (Rechtsidee), atau hukum positif dan cita hukum adalah sumber keadilan.

3. Inti dari keadilan adalah kesamaan (Gleichheit). Di sini Radbruch mengikuti pandangan Aristoteles tentang keadilan, yaitu keadilan komutatif (misalnya antara prestasi dan kontra prestasi) dan keadilan distributif (di bidang privat dan publik. Privat: gaji dibayar sesuai prestasi kerja, publik: jabatan berdasarkan kualifikasi), (Rhiti, 2011).

Berdasarkan segala yang telah diuraikan tersebut diatas, Diskresi Hakim dalam Pertimbangan hukumnya untuk menerima Perubahan Gugatan dimana telah ditambahkannya Posita Gugatan dan Petitium Gugatan meski perubahan Gugatan tersebut secara Formal bertentangan dengan Pasal 127 Rv, menurut Penulis Diskresi Hakim tersebut sudah sangat tepat dan keberanian Majelis Hakim dalam mengambil langkah Diskresi Hakim bukan didasarkan pada ketidak adilan terhadap salah satu pihak yang berperkara melainkan Undangundang memberikan ruang yang seluas-luasnya kepada Majelis Hakim dalam memberikan putusan dengan menggali hukum untuk mewujudkan keadilan yang bermanfaat dan memiliki kepastian hukum. Dalam Perkara Perceraian dan Hak Asuh Anak Nomor 4/Pdt.G/2016/PN.Pti di Pengadilan Negeri Pati dapat terlihat implementasi kekuasaan kehakiman yang merdeka demi mewujudkan produk hukum berupa putusan pengadilan yang mengedepankan keadilan, kegunaan dan kepastian hukum.

\section{Simpulan}

Kekuasaan Kehakiman adalah kekuasaan Negara yang merdeka untuk menyelenggaraan peradilan guna menegakkan hukum dan keadilan berdasarkan Pancasila dan Undang-undang Dasar Negara Republik Indonesia Tahun 1945 demi terselenggaranya Negara Hukum Republik Indonesia. Hakim bukanlah wadah Undang-undang yang hanya menerapkan Undang-undang apa adanya tanpa melihat adil ataukah tidak jika aturan tersebut diterapkan pada suatu perkara. Hakim dan Hakim konstitusi wajib menggali, mengikuti dan memahami nilai-nilai hukum dan rasa keadilan yang hidup dimasyarakat. Kewenangan Hakim menerapkan diskresi dalam mengabulkan perubahan gugatan dalam perkara perceraian dan hak asuh anak Nomor 4/Pdt.G/2016/PN.Pti di Pengadilan Negeri Pati merupakan suatu kewenangan yang dilakukan Hakim yang meyimpang dari yang telah ditetapkan oleh Undang-undang dengan mengacu pada asas sistem peradilan Negara Indonesia adalah sederhana, cepat dan biaya ringan. Kebijakan Hakim dalam mengambil Diskresi Hakim dalam perkara perceraian dan hak asuh anak Nomor 4/Pdt.G/2016/PN.Pti di Pengadilan Negeri Pati yang mengacu pada asas sistem peradilan Negara Indonesia adalah sederhana, cepat dan biaya ringan mencerminkan keadilan, kemanfaatan dan kepastian hukum. 
Hal ini sebagaimana dikemukakan Gustav Radbruch, pencetus tiga nilai dasar hukum bahwa hukum yang baik adalah ketika hukum tersebut memuat nilai keadilan, kepastian hukum dan kegunaan. Gustav Radbruch berpendapat bahwa tujuan hukum meliputi: keadilan, kegunaan dan kepastian hukum.

\section{DAFTAR PUSTAKA}

\section{Buku-buku :}

Darmodihardjo, Dardji \& Sidharta. (1995). Pokok-Pokok Filsafat Hukum, Apa dan Bagaimana Filsafat Hukum Indonesia. PT. Gramedia Pustaka Utama : Jakarta.

Muchtar, K. (2004). Asas-Asas Hukum Islam Tentang Perkawinan. Jakarta: Bulan Bintang.

Mertokusumo, S. (1988). Mengenal Hukum. Yogyakarta: Liberty.

Mertokusumo, S. (2003). Mengenal Hukum Suatu Pengantar. Yogyakarta: Liberty.

Radbruch, G. (2013). Teori Dasar Hukum/Triadism Law Theory. Bandar Lampung: Indepth Publishing.

Rhiti, H. (2011). Filsafat Hukum (dari Klasik ke Postmodernisme). Yogyakarta: Penerbit Universitas Atma Jaya.

Soemitro, R.H. (1990). Metode Penelitian Hukumdan Jurimetri. Jakarta: Ghalia Indonesia.

Soekanto, S., \& Mamudji, S. (1990). Penelitian Hukum Normatif Suatu Tinjauan Singkat. Jakarta: Rajawali Press.

\section{Artikel Jurnal :}

Busthami, D. (2017). Kekuasaan Kehakiman Dalam Perspektif Negara Hukum Di Indonesia. Masalah - Masalah Hukum, Jilid 46 (No.4, Oktober), pp.336-342. Retrieved from: https://ejournal.undip.ac.id/index.php/mmh/article/view/15548/12671.

Haryadi, L., \& Suteki. (2017). Implementasi Nilai Keadilan Sosial Oleh Hakim Dalam Perkara Lanjar Sriyanto Dari Perspektif Pancasila Dan Kode Etik Profesi Hakim. Jurnal Law Reform, Vol.13,(No.2), $\quad$ pp. $177 . \quad$ Retrieved from: https://ejournal.undip.ac.id/index.php/lawreform.

\section{Undang-undang dan Peraturan:}

Undang-undang Dasar Negara Republik Indonesia Tahun 1945.

Undang-undang Nomor 1 Tahun 1974 tentang Perkawinan.

Undang-undang Nomor 1 Tahun 1974 tentang Perkawinan Pasal 39.

Undang-undang Nomor 1 Tahun 1974 tentang Perkawinan Pasal 45. 
Undang-undang Nomor 14 Tahun 1985 tentang Mahkamah Agung.

Undang-undang Nomor 5 Tahun 2004 tentang Perubahan atas Undang-undang. No. 14 Tahun 1985 tentang Mahkamah Agung.

Undang-undang. No. 3 Tahun 2009 tentang Perubahan Kedua atas Undang-undang. No. 14 Tahun 1985 tentang Mahkamah Agung. Pasal 1 ayat (1)

Undang-undang Republik Indonesia Nomor 48 Tahun 2009 tentang Kekuasaan Kehakiman.

Undang-undang Nomor 30 Tahun 2014 tentang Administrasi Pemerintahan yang diatur dalam ketentuan Pasal 1 angka 9. 